\title{
The concept of balanced maintenance cycle of a railway vehicle
}

\section{Koncepcja zbilansowanego cyklu utrzymania pojazdu kolejowego}

\begin{abstract}
Due to various difficulties related with creation such documentation, in the hereby article the alternative concept of maintenance system for six axles, heavy diesel locomotive will be presented, which is based on balancing the scopes of maintenance activities on particular levels of maintenance. The main assumptions proposed solution will be evenly distribution in time the preventive maintenance activities between particular maintenance levels with parallel keeping the safety operation and extension of components usage. It will be advisable to use the FMEA method (Failure Mode and Effects Analysis) in order to change the scope and frequency of particular levels of maintenance. The benefits and risks of a balanced model will also be presented in comparison to the classic, five-levels maintenance system. An analysis of both maintenance models of traction vehicles will be made in the context of the costs of preventive inspections and repairs.
\end{abstract}

Przedsiębiorstwa kolejowe sq zobowiqzane do posiadania dokumentacji utrzymania pojazdów kolejowych. W zwiazku z różnymi trudnościami zwiqzanymi z opracowywaniem takiej dokumentacji $w$ niniejszym artykule zaprezentowana zostanie alternatywna koncepcja utrzymania sześcioosiowej, ciężkiej lokomotywy spalinowej polegajaca na zbilansowaniu zakresów utrzymania na poszczególnych poziomach. Głównymi założeniami proponowanego rozwiazania będzie równomierne rozłożenie $w$ czasie czynności przegladowo-naprawczych pomiędzy danymi poziomami utrzymania przy jednoczesnym zapewnieniu bezpiecznej eksploatacji i wydtużenia okresu używania poszczególnych komponentów. Na przyktadzie zastosowanej metody FMEA (ang. Failure Mode and Effects Analysis) zaprezentowany zostanie sposób doboru zakresu i częstotliwości poziomów utrzymania. Przedstawione zostanq również korzyści wynikajace z takiego modelu w porównaniu do klasycznych, pięciopoziomowych systemów utrzymania. Dokonana zostanie analiza obu modeli utrzymania lokomotyw w kontekście ponoszonych kosztów utrzymania w cyklu życia lokomotywy.

\section{Formal and legal bases of the maintenance sys- tem documentation}

Railway companies are required to hold a documentation of the rolling stock maintenance system. The maintenance system is a comprehensive and formalized procedure related to operation and maintenance of the rail vehicles, to be obligatorily implemented by the entities involved in railway traffic. Proper construction of a safety management system, inclusive of the vehicle maintenance, requires the knowledge of the following normative acts:

- Directive 2004/49/EC of the European Parliament and the Council of April 29, 2004, on safety of the Community's railways;

- Directive 2008/110/EC of the European Parliament and the Council of December 16, 2008, amending the Directive 2004/49/EC on safety of the Community's railways (the Railway Safety Directive), establishing the Main-

\section{Podstawy formalnoprawne dla dokumentacji systemu utrzymania}

Przedsiębiorstwa kolejowe zobowiązane są do posiadania dokumentacji systemu utrzymania taboru kolejowego. System utrzymania to kompleksowy i sformalizowany sposób postępowania dotyczący eksploatacji i utrzymania pojazdów kolejowych, który musi zostać wdrożony przez podmioty biorace udział w ruchu kolejowym. Dla poprawnego zbudowania systemu zarządzania bezpieczeństwem, w tym utrzymaniem pojazdu, w szczególności konieczna jest znajomość następujących aktów normatywnych:

- Dyrektywa Parlamentu Europejskiego i Rady 2004/49/WE z 29 kwietnia 2004 r. w sprawie bezpieczeństwa kolei wspólnotowych.

- Dyrektywa Parlamentu Europejskiego i Rady 2008/110/WE z 16 grudnia 2008 r. zmieniająca dyrektywę 2004/49/WE w sprawie bezpieczeństwa kolei wspólnotowych (dyrektywę w spra- 
- tenance Management Systems of the rail vehicles;

- Commission Regulation (EC) No. 352/2009 of April 24, 2009 on adoption of a common method of safety assessment, aimed at risk evaluation and appraisal, mentioned in Article 6 par. 3 Item a) of the Directive 2004/49/EC of the European Parliament and the Council;

- Ordinance of the Minister of Infrastructure of October 12, 2005, on general technical conditions related to operation of railway vehicles (Journal of Laws of 2016, item 226, as amended).

Directive 2004/49/EC determines minimum requirements related to the railway system, while the Regulation of the Minister of Infrastructure of October 12,2005 , on general technical conditions of railway vehicles operation more exactly clarifies what requirements should be met by the Maintenance System Documentation (MSD) of the railway vehicle.

The Directive 2004/49/EC determines minimum requirements for the railway system, while the Regulation of the Minister of Infrastructure of October 12,2005 , on general technical conditions for railway vehicles operation specifies exactly what requirements should be met by the maintenance system documentation (DSU) of the railway vehicle.

While describing the maintenance management rules of the railway vehicles, the concept of vehicle life cycle should be taken into account, i.e. the time elapsing since the beginning of the vehicle project until the end of its operational period, equivalent to physical liquidation of the vehicle.

The life cycle may be divided into three main stages [1]:

I. Production:

a) design;

b) manufacturing.

II. Operation:

a) the use;

b) maintenance (maintenance activity and management).

III. Liquidation:

a) decommissioning;

b) recycling of physical liquidation of the vehicle.

The paper is devoted to the $2^{\text {nd }}$ stage, particularly to management of the documentation and maintenance activity.

\section{Documentation of the maintenance system}

In accordance with current regulations, railway carriers are allowed to operate the railway vehicles provided they hold the maintenance system documentation. The railway carrier is required to develop such a documentation for a given vehicle type. The documentation itself should be consistent with operational wie bezpieczeństwa kolei), wprowadzająca Systemy Zarządzania Utrzymaniem pojazdów kolejowych.

- Rozporządzenie Komisji (WE) NR 352/2009 z 24 kwietnia 2009 r. w sprawie przyjęcia wspólnej metody oceny bezpieczeństwa $\mathrm{w}$ zakresie wyceny i oceny ryzyka, o której mowa w art. 6 ust. 3 lit. a) Dyrektywy 2004/49/WE Parlamentu Europejskiego i Rady.

- Rozporządzenie Ministra Infrastruktury z 12 października 2005 r. w sprawie ogólnych warunków technicznych eksploatacji pojazdów kolejowych (Dz. U. 2016 poz. 226 z późn. zm.).

Aktualnie obowiązujące przepisy wskazują, że każdy pojazd kolejowy powinien mieć przypisaną jednostkę odpowiedzialną za jego utrzymanie, tzw. ECM (ang. Entity in Charge of Maintenance). Jednostka ta jest odpowiedzialna za takie określenie zasad utrzymania pojazdów kolejowych oraz ich należyte utrzymanie, aby ich eksploatacja była bezpieczna dla wszystkich uczestników ruchu kolejowego.

Dyrektywa 2004/49/WE wskazuje na minimalne wymagania dla systemu kolejowego, a Rozporządzenie Ministra Infrastruktury z 12 października 2005 r. w sprawie ogólnych warunków technicznych eksploatacji pojazdów kolejowych doprecyzowuje, jakie konkretnie wymagania powinna spełniać dokumentacja systemu utrzymania (dalej: DSU) pojazdu kolejowego.

Opisując zasady zarządzania utrzymaniem pojazdów kolejowych należy również zwrócić uwagę na pojęcie cyklu życia pojazdu, którym jest okres od chwili uruchomienia projektu pojazdu do końca jego eksploatacji, czym jest najczęściej fizyczna likwidacja pojazdu. [1]:

Cykl życia można podzielić na trzy główne etapy

I. produkcja:

a) projektowanie,

b) wytwarzanie,

II. eksploatacja:

a) użytkowanie,

b) utrzymanie (zarządzanie utrzymaniem oraz czynności utrzymaniowe),

III.likwidacja:

a) wycofanie $z$ eksploatacji,

b) recykling pojazdu lub jego fizyczna likwidacja.

$\mathrm{W}$ artykule analizie poddany został etap II, w szczególności w zakresie zarządzania dokumentacją oraz czynnościami utrzymaniowymi.

\section{Dokumentacja systemu utrzymania}

Zgodnie z aktualnie obowiązującymi przepisami, przewoźnicy kolejowi mogą eksploatować pojazdy kolejowe tylko wtedy, gdy posiadają one dokumentację systemu utrzymania. Przedsiębiorca kolejowy jest zobowiązany do opracowania takiej dokumentacji dla danego typu pojazdu, która odpowiada warunkom. 
conditions existing at the carrier's. It means that to particular vehicle type various MSDs may be assigned, depending on which carrier operates the vehicle and according to its individual operating conditions. Difficult and heavy-duty operating conditions will impose other vehicle maintenance than in case of systematic and moderate operations carried out with the same vehicle. Therefore, the legislator obliged, among others the carriers, to develop and to own the MSD, allowing even to resign from its approval by the President of the Office of Rail Transport, being a market regulator. Thus, the railway companies achieved a certain freedom in determining the rules, manner and regime of the railway vehicles maintenance, nevertheless, bearing full responsibility for their safe operation. This allowed the railway companies to adopt various maintenance concepts under the rules provided in the Regulation of the Minister of Infrastructure of October 12,2005 on general technical conditions for railway vehicles operation.

\subsection{A five-level maintenance cycle}

The most common maintenance system consists in division of the operations into the so-called light- and heavy-duty maintenance. Light-duty maintenance includes the so-called P1, P2 and P3 levels, while the P4 and P5 [2] levels belong to heavy-duty maintenance operations. The first three levels are often referred to as inspections, while the last two ones are repair levels, including revisions $(\mathrm{P} 4)$ and major overhauls (P5). The entire maintenance period is called the inspection-repair cycle.

The classical model of such a cycle based on approved documentation of the diesel locomotive maintenance system is shown in Fig. 1.

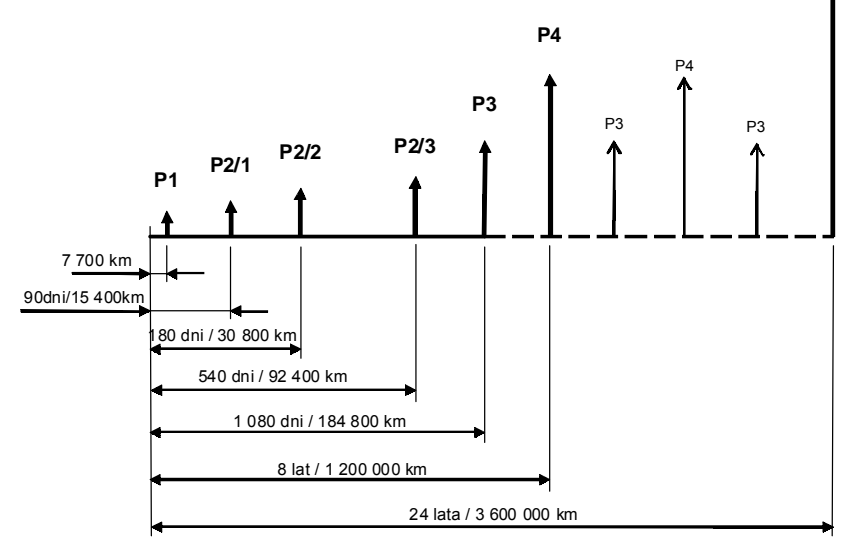

Fig. 1. Example of the Co'-Co' diesel locomotive maintenance cycle $(\mathrm{dni}=$ days; lata $=$ years $)$

Rys. 1. Przykład cyklu utrzymania dla lokomotywy spalinowej Co'-Co'

The P1 maintenance level includes checking or monitoring carried out prior to railway vehicle entering the railway. These operations may be carried out by the carrier's employees (train driver, inspector) or with the use of automated on-board devices. eksploatacji przez tego przewoźnika. Oznacza to, że dany typ pojazdu może posiadać różne DSU, w zależności od tego, który przewoźnik używa pojazd i zależnie od jego indywidualnych warunków eksploatacji. Trudne i ciężkie warunki eksploatacji będą wymagały innego utrzymania pojazdu aniżeli systematyczne i umiarkowane operacje z użyciem tego samego pojazdu. Dlatego też ustawodawca zobowiązał do opracowania i posiadania DSU właśnie m.in. przewoźników i wyłączył nawet konieczność zatwierdzania takiej dokumentacji przez Prezesa Urzędu Transportu Kolejowego, jako regulatora rynku. Przedsiębiorstwa kolejowe uzyskały zatem pewną swobodę ustalania zasad, sposobu i reżimu utrzymania pojazdów kolejowych, ponosząc jednocześnie pełną odpowiedzialność za ich bezpieczną eksploatację. Swoboda ta spowodowała, że przedsiębiorstwa kolejowe przyjmują różne koncepcje utrzymania w ramach reguł opisanych Rozporządzeniem Ministra Infrastruktury z 12 października 2005 r. w sprawie ogólnych warunków technicznych eksploatacji pojazdów kolejowych

\subsection{Pięciopoziomowy cykl utrzymania}

Najczęściej spotykanym systemem utrzymania jest przyjęcie podziału na tzw. utrzymanie lekkie i ciężkie. Do lekkiego utrzymania zalicza się tzw. poziomy P1, P2 i P3, natomiast do utrzymania ciężkiego poziomy P4 i P5 [2]. Często pierwsze trzy poziomy określa się przeglądami, a ostatnie dwa poziomami naprawczymi, do których zalicza się rewizje (P4) oraz naprawy główne (P5), natomiast cały okres utrzymania pojazdu przyjęło nazywać się cyklem przeglądowo-naprawczym.

Klasyczny model takiego cyklu na podstawie zatwierdzonej dokumentacji systemu utrzymania lokomotywy spalinowej przedstawiono na rys. 1 .

Poziom utrzymania P1 zawiera czynności sprawdzające lub monitoring, dokonywane przed wyjazdem pojazdu kolejowego na drogę kolejową. Czynności mogą być wykonywane przez pracowników przewoźnika (maszynistę, rewidenta) lub przy użyciu automatycznych urządzeń pokładowych.

Poziom utrzymania 2 obejmuje czynności, które zapobiegają przekroczeniom limitów zużycia. Wykonywane są $\mathrm{w}$ określonych odstępach czasu lub po uzyskaniu określonego limitu przebiegu. Często w ramach poziomu P2 wyróżnia się podpoziomy P2/1, $\mathrm{P} 2 / 2$ itd.

Poziom utrzymania 3 zawiera czynności z zakresu utrzymania, które zapobiegają przekroczeniu limitów zużycia, Wykonywane są po wyłączeniu pojazdu $\mathrm{z}$ planowanej eksploatacji w wyspecjalizowanych zakładach naprawczych. Podczas takiego przeglądu następuje szczegółowa ocena stanu technicznego pojazdu kolejowego poprzez sprawdzenie działania obwodów, oględziny podzespołów określonych w dokumentacji dostępnych po demontażu, a także przewi- 
The maintenance level 2 includes the operations that prevent exceeding the wearing limits. They are carried out at specified intervals or at a specified mileage limit. The P2/1, P2/2 sublevels etc. are often distinguished within the $\mathrm{P} 2$ level.

Maintenance level 3 includes the operations that prevent exceeding the wearing limits. These operations are carried out after the break in planned vehicle use due to temporary shutdown for its reviewing in a specialized repair center. Such a review is aimed at detailed assessment of technical condition of the railway vehicle and includes a check of electric circuits operation, inspection of the subassemblies indicated by documentation and accessible after vehicle dismantling, as well as diagnostic tests provided for in the documentation.

Maintenance level $\mathbf{4}$ defines the operations carried out as a part of a repair. This level includes a detailed check of technical conditions defined by the documentation of subassemblies and assemblies dismantled from the railway vehicle. The components and assemblies are replaced or regenerated when it is required by MSD.

Maintenance level 5 is aimed at reinstatement of the construction parameters and standard of a railway vehicle, inclusive of its renewal or reconstruction. The repair of the P5 level includes dismantling of the assemblies and subassemblies from the railway vehicle and their replacement with new ones or regeneration in a broader scope than in case of P4 level.

The inspection and repair cycle indicated above, with proper definition of the maintenance operations belonging to a given level, enables safe operation of the vehicle. This frequently results from the recommendations of the manufacturer of the vehicle itself or its particular parts. Nevertheless, it entails a regime consisting in necessary deliverance of the vehicle for inspections or repairs. These operations are carried out at specific intervals, thus causing the vehicle shutdown for unpredictable period of time. Moreover, it is very difficult to predict which subassembly or part should be replaced or regenerated at a given maintenance cycle level. The need of replacement or regeneration may be assessed only for disassembled and measured parts or subassemblies. This, in turn, imposes unplanned extension of the repair or inspection, that is always only hardly accepted by the carrier, as causing carrier's additional costs or contractual penalties for not performed transport tasks.

An additional obstacle for the carrier occurs in case of vehicle defect causing its shutdown and needing an emergency repair. Such repairs are unpredictable, the vehicle must be delivered to a specialist repair shop and remains out of service for an additional unplanned time.

The maintenance costs are also significant. In case of the cycle shown in Fig. 1 they grow with increasing dziane w dokumentacji badania diagnostyczne.

Poziom utrzymania 4 definiuje czynności wykonywane $\mathrm{z}$ zakresu utrzymania naprawczego. W ramach tego poziomu następuje szczegółowe sprawdzenie stanu technicznego przewi dzianych $\mathrm{w}$ dokumentacji podzespołów i zespołów, połączone $\mathrm{z}$ ich demontażem z pojazdu kolejowego. Następuja planowe wymiany podzespołów i zespołów lub ich regeneracje, jeżeli wg DSU są konieczne.

Poziom utrzymania 5 to czynności mające na celu przywrócenie konstrukcyjnych parametrów i standardu pojazdu kolejowego, w tym jego odnowienie lub odbudowę. Podczas naprawy poziomu P5 następuje demontaż zespołów i podzespołów z pojazdów kolejowych i ich wymiana na nowe lub zregenerowane, w szerszym zakresie aniżeli podczas poziomu $\mathrm{P} 4$.

Wskazany powyżej cykl przeglądowo-naprawczy przy odpowiednim zdefiniowaniu czynności utrzymaniowych w ramach danego poziomu pozwala na bezpieczną eksploatację pojazdu. Często też wynika z zaleceń producenta pojazdu lub poszczególnych podzespołów. Jednakże jego wadą jest to, iż wymaga zachowania reżimu, który powoduje konieczność dokonywania zjazdów pojazdów na przeglądy bądź naprawy, które dokonywane są wprawdzie co określony okres czasu, jednak powodujące wyłączenie pojazdu na różne okresy czasu. Ponadto bardzo trudne do przewidzenia jest to, który z podzespołów lub część będą wymagały wymiany lub regeneracji na określonym poziomie cyklu utrzymania. Najczęściej okazuje się bowiem po dokonanych demontażach i pomiarach części lub podzespołów, który z nich nie spełnia granicznych parametrów i wymaga wymiany na nowy lub regeneracji. To zaś powoduje nieplanowane wydłużenie naprawy lub przeglądu, które zawsze jest bardzo trudne do akceptacji przez przewoźnika, co z kolei generuje dodatkowe koszty po jego stronie lub naliczanie kar umownych $\mathrm{z}$ tytułu nie realizowanych zadań przewozowych.

Dodatkowym utrudnieniem dla przewoźnika są również usterki pojazdów powodujące ich wyłączenie z eksploatacji i konieczność dokonania napraw awaryjnych. Naprawy te są trudne do przewidzenia, wymagają często zjazdu do specjalistycznego warsztatu naprawczego i powoduja dodatkowe nieplanowane wyłączenie pojazdu z eksploatacji.

Nie bez znaczenia są również koszty utrzymania, które w cyklu opisanym na rys. 1 są tym wyższe im wyższy jest poziom utrzymania, np. dla lokomotywy spalinowej ok. 2000 PLN dla poziomu P1 i ok. 1.300.000 PLN dla poziomu utrzymania P5. Nie zawsze wyższe koszty w danym okresie mogą zostać zrekompensowane podniesieniem cen usług na rynku. Tak duża różnica powoduje, iż w przypadku kumulacji napraw P4 i P5 w jednym roku budżetowym przedsiębiorstwa, występują bardzo wysokie koszty prowadzonej działalności, to zaś skutkuje niską rento- 
maintenance level. For example in case of a diesel locomotive the cost amounts about to PLN 2,000 for P1 level and about to PLN 1,300,000 for the maintenance level P5. Higher costs incurred in a given period not always may be compensated by raised prices of the market services. Such a large difference means that in case of accumulation of $\mathrm{P} 4$ and $\mathrm{P} 5$ repairs in one company's financial year very high costs of the activity are generated. This, in turn, results in low profitability or even loss on the business activity. The P4 and P5 repair levels require some critical market resources, e.g. wheelsets, traction motors. In consequence, larger number of these repairs in short time may result in temporary lack of these subassemblies, thus resulting in unplanned extended repair duration.

In order to avoid unplanned emergency repairs or increased repair range within the scheduled P1 and P5 maintenance operations a so-called balanced vehicle maintenance system is recommended that is already used by some carriers on the Polish freight transport markets.

\subsection{Balanced maintenance cycle}

The concept of a balanced vehicle maintenance cycle is based on even distribution of the inspection and repair operations during the vehicle lifetime or full maintenance cycle. A basis for MSD development, that adopts similar review scopes consists, in particular, in thorough analysis of:

a) documentation and recommendations of the vehicle manufacturer;

b) technical \& operational documentation;

c) current maintenance system documentation;

d) elements of short service life;

e) limit repair and construction values of the vehicle;

f) wear of the parts and subassemblies, i.e. loss of physical properties (geometric, mechanical, dielectric, etc.) by an assembly, subassembly or component as a result of normal operation and environmental impact;

g) vehicle breakdown frequency;

h) the catalog of standards, obligatory and recommended UIC cards related to construction and repair of the vehicle and its parts and assemblies.

The concept of balanced maintenance is presented on the example of a heavy diesel Co'-Co' locomotive, allowed to be operated in Poland.

In order to analyze the above-mentioned elements the team of experts should examine and estimate how all the inspection and repair operations might be divided with a view:

a) to keep the locomotive downtime duration as short as possible, e.g. 7 to 14 days;

b) to prevent worsening of availability and reliability of the locomotive assumed by the wnością, a często nawet stratą na prowadzonej działalności gospodarczej. Ponadto w przypadku wykonywania napraw P4 i P5 w krótkim okresie czasu może również nastąpić problem $\mathrm{z}$ dostępnością na rynku krytycznych zasobów, np. zestawów kołowych, silników trakcyjnych, co powoduje nieplanowane wydłużenie procesu naprawy.

$\mathrm{W}$ celu uniknięcia nieplanowanych napraw awaryjnych lub zwiększonego zakresu napraw podczas wykonywania planowych zabiegów utrzymaniowych w ramach przeglądów P1 i P5 rekomenduje się przyjmowanie tzw. zbilansowanego systemu utrzymania pojazdów, który jest już stosowany przez niektórych przewoźników na polskim rynków przewozów towarowych.

\subsection{Zbilansowany cykl utrzymania}

Koncepcja zbilansowanego cyklu utrzymania pojazdu opiera się na równomiernym rozłożeniu czynności przeglądowo-naprawczych w okresie życia pojazdu lub pełnym cyklu utrzymania. Podstawą do opracowania DSU, którego założeniem są podobne zakresy przeglądów, jest w szczególności dokładna analiza:

a) dokumentacji i zaleceń producenta pojazdu,

b) dokumentacji techniczno-ruchowej,

c) aktualnej dokumentacji systemu utrzymania,

d) elementów posiadających krótką żywotność eksploatacyjna,

e) wartości kresowych, naprawczych i konstrukcyjnych pojazdu,

f) zużycia części i podzespołów tj. utrata własności fizycznych (geometrycznych, mechanicznych, dielektrycznych itp.) przez zespół, podzespół lub element w wyniku normalnej eksploatacji i oddziaływania środowiska naturalnego,

g) awaryjności pojazdu,

h) katalogu norm, kart UIC obowiązujących i zalecanych w budowie i naprawie pojazdu oraz ich części i zespołów.

Koncepcja zbilansowanego utrzymania zostanie przedstawiona na przykładzie ciężkiej lokomotywy spalinowej o układzie osi Co'-Co' posiadającej zezwolenie na eksploatację na terenie Polski.

W celu przeprowadzenia analizy ww. elementów zespół ekspertów winien zbadać i ocenić, w jaki sposób można podzielić wszystkie czynności przeglądowo-naprawcze, aby:

a) okres wyłączenia lokomotywy z eksploatacji był podobny i możliwie najkrótszy np. 7 do 14 dni,

b) zakładany przez producenta poziom dostępności i niezawodności lokomotywy nie uległ pogorszeniu,

c) zachowane zostały bezwzględnie wszelkie zasady bezpiecznej eksploatacji pojazdu, 
manufacturer;

c) to keep all the rules of safe vehicle operation;

d) to keep the costs of particular maintenance levels at similar level.

While developing a new maintenance concept a history of repairs or breakdowns of the vehicle is very helpful. It should be broken down by particular assemblies and subassemblies of the locomotive, indicating the causes of the faults. This allows to determine quite precisely the lifespan of a given subassembly, that is a prerequisite for proper planning of the term of exchange of such a subassembly prior to its probable defect. One of basic assumptions of the balanced maintenance cycle consists in predicting the exchange or regeneration of the subassemblies before an unexpected failure occurs, which would exclude the vehicle from operation and generate unpredictable consequences and costs of repair. Such an approach becomes more difficult in case of a new product without its history of repairs and defects arising during the vehicle operation.

The next stage of work aimed at developing a balanced maintenance cycle consists in thorough analysis of the scope of the actions required to ensure safe and correct operation of the locomotive. A number of components are distinguished by specific requirements and parameters that should be met for trouble-free operation. The team of experts so divides the operations as to keep these measurement standards of respective parameters with a view to avoid exceeding the limit values.

Particular maintenance operations of a given review level should be necessarily selected with consideration of the time-consumption of these operations and identification of the subassemblies to be checked. In order to determine the inspection term first of all the necessary scope of the review should be determined, with determination of the required operations. Afterwards, duration of the operations should be measured, preferably with commonly used tools (e.g. working time regulation, timing). The purpose of such an approach to the production process is proper organization of the work aimed at ensuring possibly the best work efficiency, without needless stoppages or disruptions of the production process resulting from poor work organization.

Bad work organization during the inspection may arise when selection of the operations is reasonable from the point of view of their scope, but they are related to so many locomotive components and parts that their dismantling for purposes of the measurements lasts disproportionately as compared to the measurement time. Therefore, particular operations related to a given subassembly should be grouped in order to avoid repeated dismantling and assembly operations that would result in time-wasting. a) koszty poszczególnych poziomów utrzymania były na zbliżonym poziomie.

Przy pracach nad nową koncepcją utrzymania bardzo pomocne jest posiadanie historii napraw lub awaryjności pojazdu, z podziałem na poszczególne zespoły i podzespoły lokomotywy ze wskazaniem przyczyn powstawania usterek. Na tej podstawie można relatywnie dokładnie określić czas życia danego podzespołu, co jest niezbędne do prawidłowego zaplanowania momentu wymiany takiego podzespołu przed jego prawdopodobnym ponownym defektem. Jednym $\mathrm{z}$ podstawowych założeń zbilansowanego cyklu utrzymania jest bowiem takie zaplanowanie wymiany lub regeneracji podzespołów, by ulegały one wymianie zanim nastapi ich nieplanowana awaria, która wyłączy pojazd z eksploatacji i wygeneruje trudne do przewidzenia skutki i koszty usunięcia naprawy. Zadanie to jest trudniejsze, jeżeli mamy do czynienia z nowym produktem, który nie posiada jeszcze historii napraw $i$ usterek, jakie powstają w trakcie eksploatacji pojazdu.

Kolejnym etapem prac nad stworzeniem zbilansowanego cyklu utrzymania jest dokładne przeanalizowanie zakresów czynności, jakie są wymagane w celu zapewnienie bezpiecznej i prawidłowej eksploatacji lokomotywy. Szereg podzespołów ma określone wymagania i parametry jakie powinny być spełnione dla zachowania bezawaryjnej eksploatacji. Zespół ekspertów dokonuje podziału czynności, aby zachować właśnie te standardy pomiarów poszczególnych parametrów w celu uniknięcia przekroczenia wartości kresowych.

Bardzo ważnym elementem przy doborze poszczególnych czynności utrzymaniowych danego poziomu przeglądu jest czasochłonność tych czynności oraz określenie podzespołów, które mają być poddane przeglądowi. W celu ustalenia czasu przeglądu należy w pierwszej kolejności ustalić niezbędny zakres danego przeglądu, określić czynności jakie są niezbędne do jego wykonania, a następnie dokonać pomiaru czasu wykonania czynności, najlepiej wykorzystując powszechnie stosowane narzędzia (np. normowanie czasu pracy, chronometraż). Celem takiego działania w procesie produkcji jest właściwe zorganizowanie pracy w taki sposób, aby możliwe było uzyskiwanie jak najlepszej wydajności pracy $\mathrm{i}$ aby nie następowały nieuzasadnione przestoje lub zakłócenia procesu produkcyjnego (przeglądowego) wynikające ze złego zorganizowania pracy.

Do złej organizacji pracy przy wykonywaniu przeglądu może dojść m. in. gdy dokonany podział czynności jest racjonalny z punktu widzenia zakresu, jednak dotyczy tak wielu podzespołów i elementów lokomotywy, że czas wykonania demontażu tych podzespołów w celu dokonania pomiarów jest niewspółmierny do czasu dokonania danego pomiaru. Należy w takim przypadku dokonywać grupowania poszczególnych czynności dotyczących danego podzespołu, 
Finally, in the course of the work devoted to the balanced locomotive maintenance it was assumed that the cycle shall include sixty two P2 inspections (from B1 to B62) carried out every six months and P1 inspections carried out every $13-15$ days (Fig. 2).

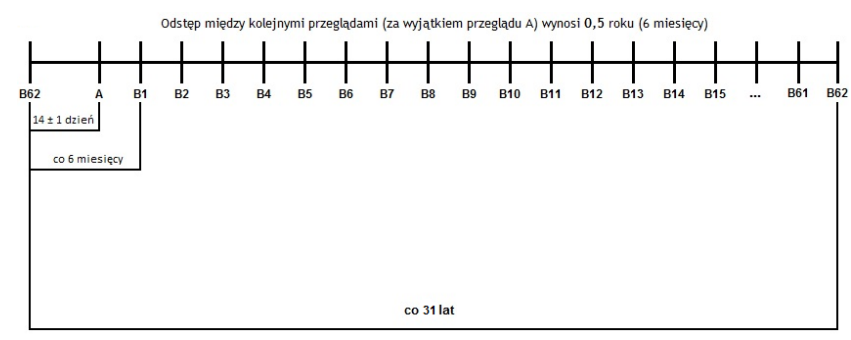

Fig. 2. Inspection and repair plan for a locomotive with balanced maintenance ranges

The source: Documentation of the diesel locomotive maintenance system. DB Cargo Polska S.A. 2017

Rys. 2. Plan przeglądowo-naprawczy lokomotywy ze zbilansowanymi zakresami utrzymania

Źródło: Dokumentacja systemu utrzymania lokomotywy spalinowej. DB Cargo Polska S.A. 2017

Przypisanie poziomów utrzymania w cyklu zbilansowanym

Tablica 1

Assignment of maintenance levels in a balanced cycle

Table 1

\begin{tabular}{|c|c|c|c|c|c|c|}
\hline & \multicolumn{5}{|c|}{$\begin{array}{c}\text { Oznaczenie i nazewnictwo przegladów i napraw } \\
\text { okresowych zgodnych z Rozporządzeniem Ministra } \\
\text { Infrastruktury }\end{array}$} \\
\hline & & P1 & P2 & P3 & P4 & P5 \\
\hline \multirow{14}{*}{ 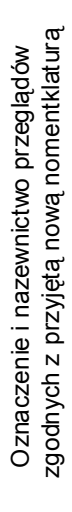 } & A & $x$ & - & - & - & - \\
\hline & B1 & $x$ & $x$ & $x$ & $x$ & $x$ \\
\hline & B2 & $x$ & $x$ & $x$ & $x$ & $x$ \\
\hline & B3 & $x$ & $x$ & $x$ & $x$ & $x$ \\
\hline & B4 & $x$ & $x$ & $x$ & $x$ & $x$ \\
\hline & B5 & $x$ & $x$ & $x$ & $x$ & $x$ \\
\hline & B6 & $x$ & $x$ & $x$ & $x$ & $x$ \\
\hline & B7 & $x$ & $x$ & $x$ & $x$ & $x$ \\
\hline & B8 & $x$ & $\mathrm{x}$ & $x$ & $x$ & $x$ \\
\hline & B9 & $x$ & $x$ & $x$ & $x$ & $\mathrm{x}$ \\
\hline & B10 & $x$ & $x$ & $x$ & $x$ & $x$ \\
\hline & B11 & $x$ & $\mathrm{x}$ & $x$ & $x$ & - \\
\hline & $\ldots$ & $\ldots$ & $\ldots$ & $\ldots$ & $\ldots$ & $\ldots$ \\
\hline & B62 & $x$ & $x$ & $x$ & $x$ & $x$ \\
\hline
\end{tabular}

Designation and terminology of periodic inspections and repairs according to the Regulation of the Minister of Infrastructure

Designation and terminology of periodic inspections and repairs according to the new nomenclature adopted

Source: Own study based on documentation of the diesel locomotive maintenance system

Źródło: Opracowanie własne na podstawie dokumentacji systemu utrzymania lokomotywy spalinowej

In order to minimize the costs and labor consumption at the maintenance levels P3, P4 and P5, the operations related to these ranges have been transferred to the respective inspection levels B1 to B62. The adopted solution ensures better use of the locomotives during the operation period and enables easier access to the materials and parts (subassemblies) of the locomotives during their repair cycle. The inspection aby nie dublować czynności demontażu i montażu urządzeń, które w procesie produkcji są traktowane jako marnotrawstwo.

Ostatecznie w toku prac nad zbilansowanym utrzymaniem lokomotywy przyjęto, że cykl ten składać się będzie z sześćdziesięciu dwóch przeglądów P2 (od B1 do B62) wykonywanych co sześć miesięcy oraz przeglądów $\mathrm{P} 1$ wykonywanych co 13 do $15 \mathrm{dni}$ (rys. 2).

W celu zminimalizowania kosztów oraz pracochłonności na poziomach utrzymania P3, P4 i P5 czynności odpowiadające tym zakresom przeniesiono odpowiednio do poszczególnych poziomów przeglądów od B1 do B62. Przyjęte rozwiązanie zapewnia również lepsze wykorzystanie lokomotyw w okresie eksploatacji oraz zabezpiecza łatwiejszy dostęp do materiałów oraz części (podzespołów) lokomotyw w cyklu ich naprawy. Poniżej w tablicy 1 przedstawiono zakresy przeglądów P1 (A) i P2, P3, P4 i P5 ujętych w poziomach $\mathrm{B} 1$ do $\mathrm{B} 62$ [3].

Poszczególne poziomy utrzymania $\mathrm{B}$ zawierają szczegółową listę czynności jakie powinny być wykonane na lokomotywie, a przypisane były do poziomów P2-P5. Tablica 2 poniżej zawiera fragment czynności utrzymaniowych przypisanych do poszczególnych poziomów utrzymania B. Symbol „x” oznacza, że podczas danego przeglądu należy wykonać określoną czynność. Tablicę opracowano na podstawie analizowanej dokumentacji systemu utrzymania lokomotywy spalinowej.

Każdy z przeglądów ma określony parametr graniczny wyrażony czasem (6 miesięcy od ostatniego poziomu Bx) oraz przebiegiem lokomotywy. Upływ założonego okresu czasu lub osiagnnięcie określonego przebiegu determinuje wykonanie kolejnego przegladu. Decyduje pierwszy osiagnięty parametr. W celu zapewnienia bezpiecznej eksploatacji pojazdu, świadectwa sprawności technicznej wystawiane są na czas i przebieg do następnego przeglądu B.

\section{Koszty cyklu utrzymania}

Bardzo ważnym elementem $\mathrm{z}$ punktu widzenia działalności przewoźnika kolejowego są koszty utrzymania taboru kolejowego. Zwłaszcza nakłady na utrzymanie lokomotyw stanowią istotną pozycją każdego budżetu przewoźnika. Dlatego ważne jest potwierdzenie, czy zbilansowany cykl utrzymania jest faktycznie korzystny z tej perspektywy.

$\mathrm{W}$ tym celu przeanalizowano koszty utrzymania trzech typów porównywalnych ciężkich, spalinowych lokomotyw o układzie osi Co'-Co' przeznaczonych do ruchu na liniach kolejowych na terenie Polski. Lokomotywy są podobne pod względem siły pociagowej, jak również pod względem konstrukcji, co uzasadnia celowość analizy wybranych lokomotyw.

Do obliczenia kosztów utrzymania lokomotywy przyjęto wszelkie koszty wykonywanych planowych 


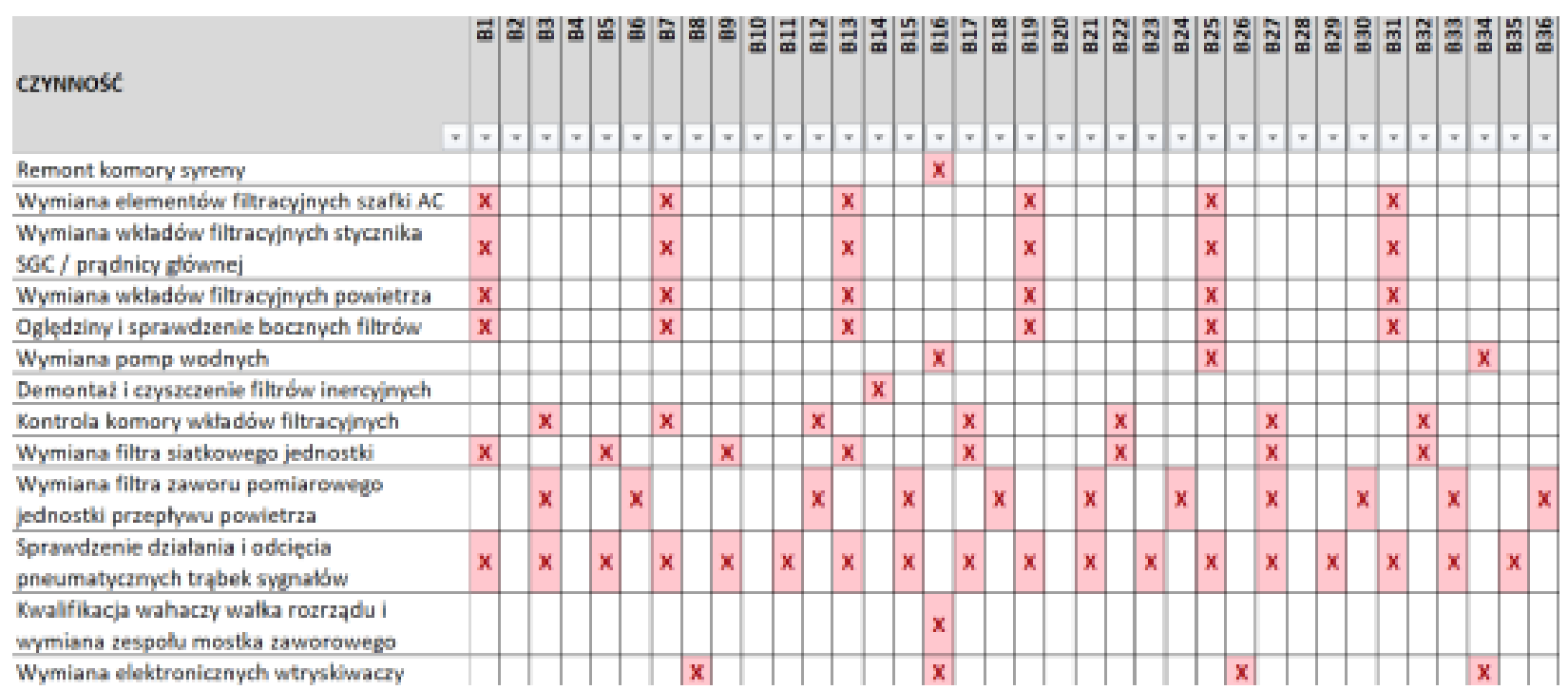

scopes P1 (A) and P2, P3, P4 and P5 belonging to the levels B1 to B62 are presented below in Table 1 [3].

Respective maintenance levels B include detailed lists of the operations previously belonging to the P2P5 levels that should be effected on the locomotive. Table 2 below presents a part of maintenance operations assigned to particular B levels of maintenance. The operations marked with " $\mathrm{x}$ " should be performed within the respective inspection. The table was developed based on the considered documentation of the diesel locomotive maintenance system.

Each inspection is distinguished by a certain limit parameter expressed by time interval (6 months from the last $\mathrm{Bx}$ level) and the locomotive mileage. When the assumed time interval expires or the specific mileage is attained, whichever occurs first, the next inspection is required. In order to ensure safe operation of the vehicle, the technical efficiency certificates are issued for the time and mileage until the next $\mathrm{B}$ inspection.

\section{Costs of the maintenance cycle}

The costs of rolling stock maintenance is very important from the point of view of the railway carrier activity. The expenditure born on maintenance of the locomotives is an important item in every carrier's budget. Therefore, it is important to confirm whether the balanced maintenance cycle is actually advantageous, looking from this perspective.

To this end, the maintenance costs of three types of similar heavy, diesel Co'-Co' locomotives intended for traffic on railway lines in Poland were analyzed. These locomotives develop similar tractive force and are distinguished by similar design. This justifies advisability of analysis of the selected locomotives.

In order to calculate the locomotive maintenance
Operation

Siren box renovation

Exchange of AC box filtration elements

Exchange of SGC/main generator filtration elements

Exchange of air filtration elements

Examination and check of side filters

Exchange of water pumps

Disassembly and cleaning of inertial filters

Control of the filter cartridges chamber

Exchange of mesh filter of the unit

Exchange of the measuring valve filter of the air flow unit

Check of efficiency of pneumatic trumpets

Check of the camshaft arms, exchange of the valve bridge assembly

przeglądów oraz napraw okresowych lokomotyw, a także awarii jakie występują w cyklu utrzymania. W kalkulacji ujęto również koszt materiałów oraz usług obcych, jakie zostały poniesione w celu wykonania utrzymania. W przypadku lokomotywy posiadającej zbilansowany cykl utrzymania przyjęto również historycznie ponoszone koszty wykonania przeglądów, natomiast dla poziomów utrzymania przeglądów $\mathrm{B}$, które jeszcze nie wystapiły, przyjęto planowana, znormowaną liczbę roboczogodzin, materiały i usługi obce, jakie są planowane przy wykonywaniu przeglądów. Wyniki porównania kosztów utrzymania lokomotyw przedstawia poniższy wykres. Zestawienie wykonano na podstawie danych pochodzących ze zintegrowanego systemu zarządzania przewoźnika, w którym zbierane są wszystkie koszty zarządzania taborem kolejowym. Lokomotywy z oznaczeniem 1 i 2 posiadają klasyczny pięciopoziomowy system utrzymania, natomiast lokomotywa z oznaczeniem 3 posiada zbilansowany cykl utrzymania podzielony na 62 przeglądy (rys. 3).

Jak wynika $\mathrm{z}$ powyższego zestawienia koszty utrzymania lokomotywy posiadającej zbilansowany cykl utrzymania są odpowiednio o 13 i 10\% niższe od pozostałych lokomotyw eksploatowanych przez przewoźnika, oznaczonych 1 i 2. 
costs all the costs of scheduled inspections and periodic repairs of the locomotives have been considered, inclusive of the failures arising in the maintenance cycle. The calculation includes also the cost of materials and contracted services incurred for the purpose of maintenance. In case of a locomotive with balanced maintenance cycle, historical maintenance costs have been also considered. For the maintenance B levels that have not yet occurred, the planned standard number of man-hours, material and contracted services have been considered, which are expected during the inspections. The results of comparison of the maintenance costs of the locomotives are presented in the graph below. The list was made based on the data extracted from the integrated management system of the carrier, including all the costs of rolling stock management. The locomotives marked with 1 and 2 underwent a classical five-level maintenance system, while the locomotive 3 is subjected to balanced maintenance cycle divided into 62 inspections (Figure 3 ).

The above specification indicates that maintenance cost of a locomotive with balanced maintenance cycle is 13 and $10 \%$ lower, respectively, as compared to the other locomotives of the carrier, marked with 1 and 2.

\section{Availability of the locomotives}

In order to get a full list of the advantages and disadvantages of the considered maintenance systems, comparison of technical availability of the locomotives is important. For a carrier it is one of basic parameters, that depends not only on operating costs, but also on consequences of delays in transport services, unpunctual arrivals and departures of the train, or loss of reputation due to unreliable service provision.

Accessibility is a percentage of the time within which the locomotive is technically sound and operational, as shown in Table 3. The locomotive remains unavailable during its scheduled inspections and repairs and during the shutdown time necessary for emergency repairs on the route or at the workshop, inclusive of travel time to the workshop in order to remove a failure that cannot be removed on the route.

According to the above specification, availability of the locomotive subjected to balanced maintenance cycle is at a good level, its failure rate did not increase.

Nevertheless, it should be noticed that in a balanced maintenance cycle a certain failure rate of the locomotive assemblies and subassemblies is assumed. In consequence, this allows to determine the terms of their verification, repair or exchange. However, it may turn out that the adopted time intervals are insufficient or the components are subject to wear earlier than before, due to the changes in operating conditions. Unplanned failures or component damages can then arise. In such a case the entire maintenance cycle should be re-examined and the ranges, the rates of maintenance operations, measurements and tests

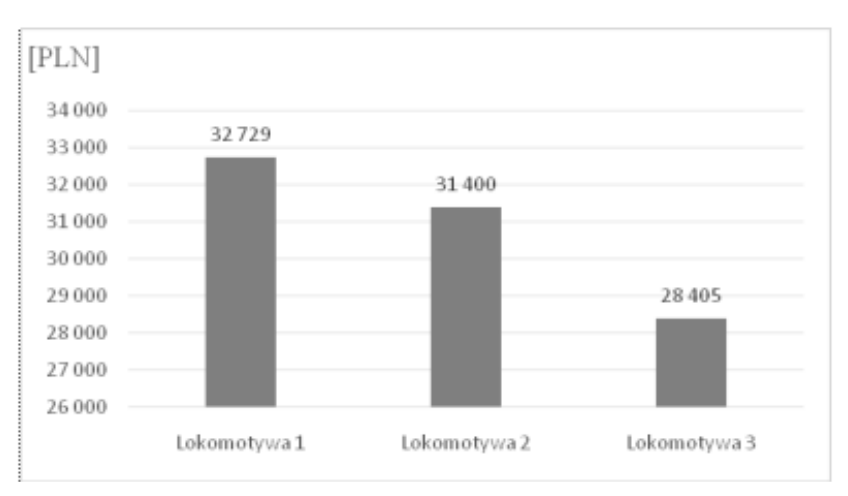

Fig. 3. Average unit monthly cost of locomotive maintenance Rys. 3. Średni jednostkowy miesięczny koszt utrzymania lokomotywy

\section{Dostępność lokomotyw}

Aby uzyskać pełny obraz zalet i wad analizowanych systemów utrzymania ważne jest porównanie dostępności technicznej lokomotyw. Jest to jeden $z$ podstawowych parametrów dla przewoźnika, od którego zależą nie tylko koszty eksploatacji, ale również konsekwencje wynikające $\mathrm{z}$ opóźnień $\mathrm{w}$ realizacji przewozów, niedochowania punktualności przyjazdu i odjazdu pociagu, czy wreszcie utraty reputacji z powodu nierzetelnego realizowania usług.

Dostępność jest to wyrażona w procentach wartość czasu, w którym lokomotywa jest sprawna technicznie i nadaje się do eksploatacji, co przedstawiono w tablicy 3. Do czasu niedostępności lokomotywy zalicza się czas planowych przeglądów i napraw lokomotyw oraz czas wyłączenia na naprawy awaryjne na szlaku lub w warsztacie, przy czym czas przejazdu do warsztatu w celu usunięcia awarii, której nie udało się usunąć na szlaku, jest liczony jako czas, w którym lokomotywa nie jest dostępna.

Technical availability of the locomotives

Table 3

Dostępność techniczna lokomotyw

Tabela 3

\begin{tabular}{|l|c|c|c|}
\hline & $\mathbf{2 0 1 5}$ & $\mathbf{2 0 1 6}$ & $\mathbf{2 0 1 7}$ \\
\hline $\begin{array}{l}\text { Lokomotywa 1- } \\
\text { cyk1 P1-P5 } \\
\text { Locomotive 1 }\end{array}$ & $94 \%$ & $91 \%$ & $92 \%$ \\
\hline $\begin{array}{l}\text { Lokomotywa 2 - } \\
\text { cyk1 P1-P5 } \\
\text { Locomotive 2 }\end{array}$ & - & $80 \%$ & $81 \%$ \\
\hline $\begin{array}{l}\text { Lokomotywa 3- } \\
\text { cyk1 P1-P62 } \\
\text { Locomotive 3 }\end{array}$ & $84 \%$ & $85 \%$ & $89 \%$ \\
\hline
\end{tabular}

Source: Own study based on the carrier's data on availability of the locomotives

Źródto: Opracowanie wtasne na podstawie danych przewoźnika o dostepności lokomotyw.

Zgodnie z powyższym zestawieniem dostępność lokomotywy, wobec której zastosowano zbilansowany cykl utrzymania jest na dobrym poziomie i nie wystapiła zwiększona awaryjność lokomotyw. 
should be adjusted accordingly. The locomotive components must then be exchanged more frequently that shall undoubtedly affect availability and maintenance costs of the locomotive.

Taking into account that such an analysis is very complex and many factors should be considered, it is advisable to use the tools that systematize the task and enable to minimize or exclude the errors. The analysis should be carried out preferably prior to implementation of the change. Alternatively, it can be performed in the course of the implementation, in order to identify potential or revealed process flaws and to plan appropriately preventive measures.

\section{Failure Mode Effect Analysis (FMEA)}

One of the methods used in analysis of the causes and effects of failures, aimed at reducing probability of their occurrence, is FMEA. It is used by the companies to prevent or mitigate the defect results that occur in the designing and manufacturing processes. The method is used to examine all possible defects before approval of a given solution, while in case of an examination process being in course the existing or possible defects are reported. Its ultimate goal consists in estimation of the risks associated with the planned or adopted solution. Thus, FMEA allows to implement the principle of minimizing defects, continuous improvement and reducing the quality cost of the process or product.

The FMEA method is widely used because of its effectiveness in analysis of complex processes. It enables analysis of a single component (e.g. a wheelset), a subassembly (e.g. a bogie) as well as the entire product (e.g. a locomotive).

Proper implementation of the FMEA requires the following steps [4]:

a) definition of the sub-assembly to be studied;

b) presentation of a list of possible defects or flaws of the considered part;

c) formulation of a list of probable consequences of the indicated defects;

d) preparation of a list of the causes resulting in the identified defects;

e) analysis of potential defects;

f) determination of the risk caused by the errors;

g) planning and implementation of preventive measures and tests of their effectiveness.

For each defect/flaw of the subassembly, their causes and effects, the following parameters are determined, scoring them on a scale of 1-10:

a) probability $(\mathrm{R})$ of the defect,

b) the meaning of the defect $(\mathrm{Z})$ for the carrier or vehicle maintainer,

c) probability (W) of finding a defect by the carrier or vehicle maintainer.

Members of the team of experts using the FMEA determine the $\mathrm{R}, \mathrm{Z}$ and $\mathrm{W}$ values, taking into account
Należy jednak zauważyć, że w zbilansowanym cyklu utrzymania zakłada się określoną awaryjność zespołów i podzespołów lokomotywy i na tej podstawie określa się czas ich weryfikacji, naprawy lub wymiany. Może się jednak okazać, że przyjęte czasookresy okażą się niewystarczające lub na skutek zmian warunków eksploatacji zużycie podzespołów będzie następowało szybciej aniżeli odbywało się to dotychczas. Dojdzie wówczas do powstawania nieplanowanych awarii lub uszkodzeń podzespołów. W takim przypadku konieczne będzie ponowne przeanalizowanie całego cyklu utrzymania, skorygowanie zakresów oraz czynności utrzymania i zagęszczenie pomiarów, testów lub wymian podzespołów lokomotywy, co niewątpliwie wpłynie ostatecznie na jej dostępność i koszty utrzymania.

$\mathrm{Z}$ uwagi na fakt, iż taka analiza jest bardzo złożona i powinna wziąć pod uwagę wiele czynników, celowe jest posłużenie się narzędziami, które systematyzują prace i pozwalają zminimalizować lub wykluczyć popełnienie błędów. Analizę taką najlepiej wykonać przed wdrożeniem zmiany. Można ją również wykonać po rozpoczęciu wdrożenia w celu zidentyfikowania potencjalnych lub ujawnionych wad procesu i odpowiedniego zaplanowania działań zapobiegawczych.

\section{Analiza FMEA}

Jedną z metod wykorzystywanych podczas analizowania przyczyn i skutków awarii oraz zmierzających do zmniejszenia prawdopodobieństwa ich wystapienia, jest analiza FMEA (ang. Failure Mode Effect Analysis). Jest ona wykorzystywana przez przedsiębiorstwa do zapobiegania lub niwelowania skutków wad, które występują w procesach konstrukcyjnych i wytwórczych. Zastosowanie metody polega na badaniu wszystkich możliwych usterek przed zatwierdzeniem danego rozwiązania, a w przypadku już istniejącego procesu badaniu występujących lub możliwych do wystapienia wad. Jej ostatecznym celem jest ocena ryzyka związanego z planowanym lub przyjętym rozwiązaniem. Tym samym FMEA pozwala na realizowanie zasady minimalizacji defektów, ciagłego doskonalenia oraz obniżania kosztów jakości procesu lub produktu.

Metoda FMEA znajduje szerokie zastosowanie, ponieważ jest skuteczna przy analizie złożonych procesów. Analizie można poddać zarówno pojedynczy komponent (np. zestaw kołowy), jak również podzespół (np. wózek) jak i cały produkt (np. lokomotywa).

Prawidłowe przeprowadzenie analizy FMEA wymaga podjęcia następujących kroków [4]:

a) zdefiniowanie podzespołu będącego przedmiotem badania,

b) przedstawienie listy możliwych wad lub usterek w odniesieniu do zdefiniowanego elementu, 
the numerical weights agreed for each subassembly for particular indicators. For example, in case of an unlikely or very rare occurrence of the defect the R indicator should be set at 1 or 2 , while for frequent or very frequent occurrence, the proper value of the indicator should amount to 9-10. The same procedure applies to determination of the Z-defect significance indicator and the $\mathrm{W}$-index evaluating probability of the defect detection.

For analytical purposes, the risk level indicator $\mathrm{C}$ is used, being a product of $\mathrm{R}, \mathrm{Z}$ and $\mathrm{W}$ parameters. The higher the product, the more important is the defect for efficient operation of the vehicle.

$$
C=R \times Z \times W
$$

It is assumed that the defect of the number $\mathrm{C}$ exceeding 121 is significant. It should be noticed that the higher the $\mathrm{C}$ value, the more serious and severe the risk to the vehicle. The value of parameter $\mathrm{C}$ above 150 indicates a critical hazard for the product.

Based on the risk matrix (Table 4), the following risk levels are specified:

a) unacceptable risk, significantly jeopardizing safety of the vehicle: corrective measures should be undertaken immediately - the risk class 1 ;

b) acceptable risk, nevertheless appropriate measures should be taken - the risk class 2 ;

c) acceptable risk, no action required - the risk class 3 .

The risk matrix C. Risk acceptability level

Table 4 Macierz ryzyka C. Poziom akceptowalności ryzyka Tablica 4

\begin{tabular}{|c|c|c|}
\hline $\begin{array}{c}\text { Klasa ryzyka } \\
\text { Risk class }\end{array}$ & $\begin{array}{c}\text { Ryzyko C } \\
\text { Risk C }\end{array}$ & $\begin{array}{c}\text { Poziom ryzyka } \\
\text { Risk level }\end{array}$ \\
\hline 1 & $\mathrm{C}>150$ & $\begin{array}{c}\text { Zagrożenie krytyczne istot- } \\
\text { nie zagrażające bezpieczeń- } \\
\text { stwu wyrobu } \\
\text { Critical hazard significantly } \\
\text { threatening safety of the } \\
\text { product }\end{array}$ \\
\hline 2 & $121 \leq \mathrm{C} \leq 150$ & $\begin{array}{c}\text { Należy podjąc działania } \\
\text { eliminujące ryzyko } \\
\text { The measures should be } \\
\text { taken to eliminate the risk }\end{array}$ \\
\hline 3 & $\mathrm{C}<121$ & $\begin{array}{c}\text { Nie ma ryzyka wystapienia } \\
\text { niebezpieczeństwa lub ryzy- } \\
\text { ko jest akceptowalne } \\
\text { No risk or the risk is accept- } \\
\text { able }\end{array}$ \\
\hline
\end{tabular}

Source: Formulated based on the concept of rolling stock maintenance and risk analysis implemented by the railway carrier

Źródto: Opracowano na podstawie koncepcji utrzymania taboru kolejowego $i$ analizy ryzyka utrzymania stosowanej przez przewoźnika kolejowego

Due to the fact that the risk indicator $\mathrm{C}$ depends on three factors, the corrective or preventive measures may also focus on reducing the probability or nuisance and improving detectability of the vehicle subassembly defects. c) utworzenie wykazu prawdopodobnych skutków wystąpienia wskazanych wad,

d) sporządzenie wykazu przyczyn wyodrębnionych wad,

e) analiza potencjalnych wad,

f) określenie ryzyka związanego z błędami,

g) zaplanowanie i wdrożenie działań zapobiegawczych oraz badanie ich skuteczności.

Dla każdej wady/usterki podzespołu, ich przyczyn i skutków, określa się następujące parametry, punktując je w skali $1 \div 10$ :

a) prawdopodobieństwo (R) wystąpienia wady,

b) znaczenie wady (Z) dla przewoźnika lub utrzymującego pojazd,

c) prawdopodobieństwo (W) wykrycia wady przez przewoźnika lub utrzymującego pojazd.

Członkowie zespołu ekspertów dokonujący analizy FMEA określają wartości $\mathrm{R}, \mathrm{Z}$ i $\mathrm{W}$, kierując się uzgodnionymi dla każdego podzespołu wagami liczbowymi dla poszczególnych wskaźników, np. w przypadku nieprawdopodobnego lub bardzo rzadkiego wystąpienia wady, wskaźnik $\mathrm{R}$ powinien zastać ustalony na poziomie $1 \div 2$, natomiast dla częstego lub bardzo częstego wystąpienia wad właściwa wartość wskaźnika powinna wynosić $9 \div 10$. Podobnie postępuje się przy określaniu wskaźnika znaczenia wady Z oraz wskaźnika W określającego prawdopodobieństwo wykrycia wady.

Dla celów analitycznych wykorzystuje się wskaźnik poziomu ryzyka $C$, który jest iloczynem parametrów $\mathrm{R}, \mathrm{Z}$ oraz $\mathrm{W}$. Im wyższy uzyskuje się iloczyn, tym wada jest istotniejsza dla sprawnego działania pojazdu.

$$
C=R \times Z \times W
$$

Przyjmuje się, że istotne znaczenie ma usterka, dla której liczba C jest większa niż 121. Należy zwrócić uwagę, że im większa wartość $\mathrm{C}$, tym zagrożenie jest bardziej znaczące i dotkliwe dla pojazdu. Wartość parametru C powyżej 150 oznacza zagrożenie krytyczne dla wyrobu.

Na podstawie macierzy ryzyka (tab. 4) identyfikuje się następujące poziomy ryzyka:

a) ryzyko niedopuszczalne istotnie zagrażające bezpieczeństwu pojazdu: niezwłocznie podjąć środki korygujące - klasa ryzyka 1 ,

b) ryzyko jest akceptowalne, ale należy podjąć odpowiednie środki zaradcze - klasa ryzyka 2 ,

c) ryzyko jest do zaakceptowania: nie jest konieczne podejmowanie żadnych działań - klasa ryzyka 3.

$\mathrm{Z}$ uwagi na to, że wskaźnik ryzyka $\mathrm{C}$ jest zależny od trzech obszarów, działania korygujące czy zapobiegawcze również mogą skupić się na zmniejszeniu prawdopodobieństwa, wykrywalności lub uciążliwości wad podzespołu pojazdu. 
Analysis of possible faults and their effects in case of the buffing $\&$ draw gear

Table 5

Analiza potencjalnych wad i skutków dla urządzeń cięgłowo-zderznych

Tablica 5

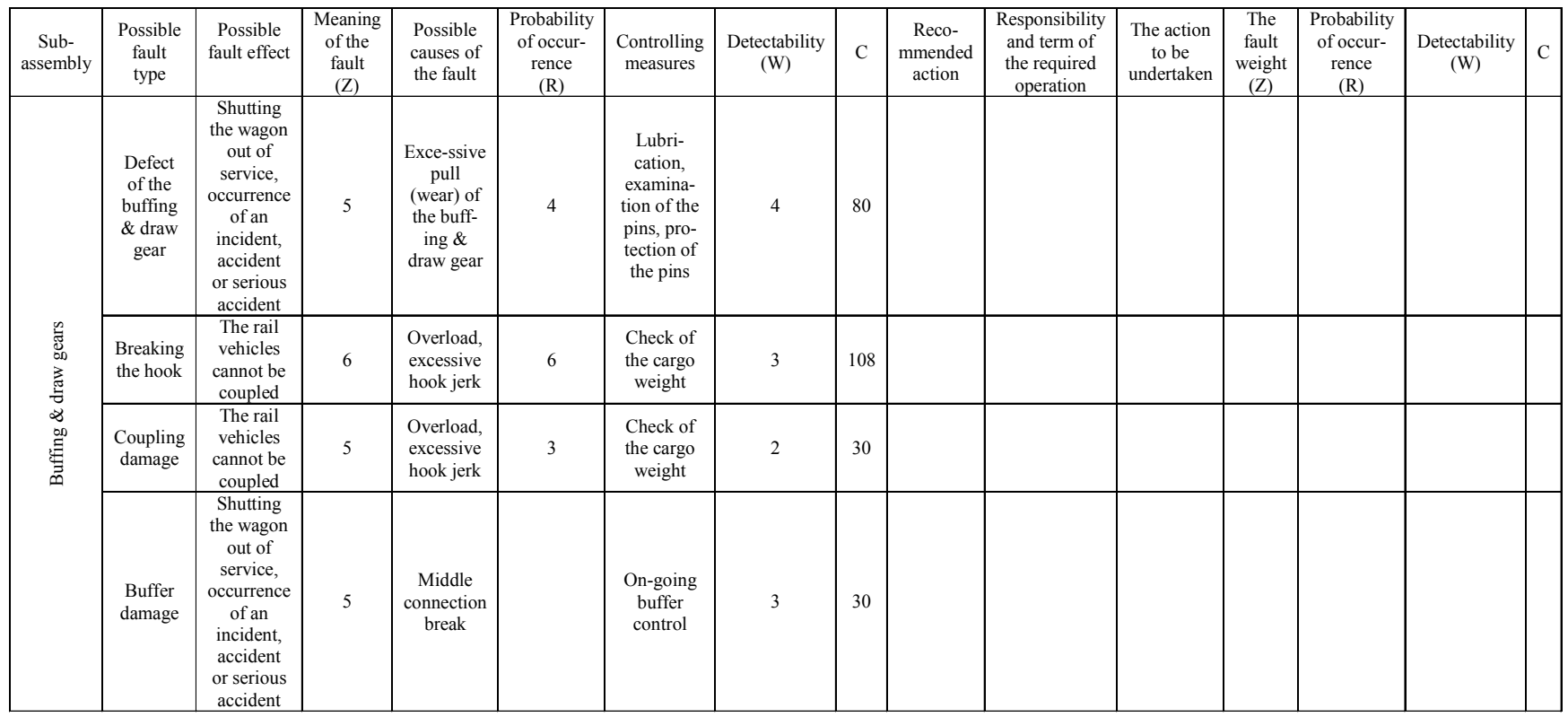

Analysis of possible faults and their effects in case of the wheelsets

Table 6

Analiza potencjalnych wad i skutków dla zestawów kołowych

Tablica 6

\begin{tabular}{|c|c|c|c|c|c|c|c|c|c|c|c|c|c|c|c|}
\hline $\begin{array}{l}\text { Sub- } \\
\text { assembly }\end{array}$ & $\begin{array}{l}\text { Possible } \\
\text { fault } \\
\text { type }\end{array}$ & $\begin{array}{c}\text { Possible } \\
\text { fault } \\
\text { effect }\end{array}$ & $\begin{array}{l}\text { Meaning } \\
\text { of the } \\
\text { fault } \\
(\mathrm{Z}) \\
\end{array}$ & $\begin{array}{l}\text { Possible } \\
\text { causes of } \\
\text { the fault }\end{array}$ & $\begin{array}{l}\text { Probability } \\
\text { of occur- } \\
\text { rence } \\
\text { (R) }\end{array}$ & $\begin{array}{l}\text { Controlling } \\
\text { measures }\end{array}$ & $\begin{array}{l}\text { Detectability } \\
\text { (W) }\end{array}$ & C & $\begin{array}{l}\text { Reco- } \\
\text { mmended } \\
\text { action }\end{array}$ & $\begin{array}{l}\text { Responsibility } \\
\text { and term of } \\
\text { the required } \\
\text { operation }\end{array}$ & $\begin{array}{l}\text { The action } \\
\text { to be under- } \\
\text { taken }\end{array}$ & $\begin{array}{c}\text { The } \\
\text { fault } \\
\text { weight } \\
(\mathrm{Z})\end{array}$ & $\begin{array}{l}\text { Probability } \\
\text { of occur- } \\
\text { rence } \\
\text { (R) }\end{array}$ & $\begin{array}{l}\text { Detecta- } \\
\text { bility } \\
\text { (W) }\end{array}$ & $\mathrm{C}$ \\
\hline \multirow{3}{*}{ 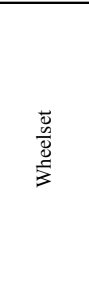 } & $\begin{array}{c}\text { Tyre } \\
\text { breakage }\end{array}$ & \multirow{3}{*}{$\begin{array}{c}\text { Shutting } \\
\text { the } \\
\text { wagon } \\
\text { out of } \\
\text { service } \\
\text { and } \\
\text { repair }\end{array}$} & 6 & $\begin{array}{c}\text { Tyre } \\
\text { breakage } \\
\text { due to } \\
\text { wear }\end{array}$ & 6 & $\begin{array}{l}\text { On-going } \\
\text { tyre control }\end{array}$ & 5 & 180 & $\begin{array}{l}\text { Tyre } \\
\text { replace- } \\
\text { ment }\end{array}$ & $\begin{array}{l}\text { Fleet man- } \\
\text { ager, immedi- } \\
\text { ately }\end{array}$ & $\begin{array}{c}\text { Tyre re- } \\
\text { placement }\end{array}$ & 5 & 6 & 5 & 150 \\
\hline & $\begin{array}{c}\text { Axis } \\
\text { breakage }\end{array}$ & & 8 & $\begin{array}{c}\text { Axis } \\
\text { breakage } \\
\text { due to } \\
\text { wear }\end{array}$ & 5 & $\begin{array}{l}\text { Defectoscopy } \\
\text { of the axis }\end{array}$ & 6 & 240 & $\begin{array}{c}\text { Axis } \\
\text { replace- } \\
\text { ment }\end{array}$ & $\begin{array}{l}\text { Fleet man- } \\
\text { ager, immedi- } \\
\text { ately }\end{array}$ & $\begin{array}{l}\text { Wheelset } \\
\text { replacement }\end{array}$ & 7 & 5 & 6 & 210 \\
\hline & $\begin{array}{c}\text { Bearing } \\
\text { breakage }\end{array}$ & & 4 & $\begin{array}{c}\text { Bearing } \\
\text { seizure, } \\
\text { lack of } \\
\text { lubrication }\end{array}$ & 7 & $\begin{array}{l}\text { Lubrication, } \\
\text { visual ex- } \\
\text { amination }\end{array}$ & 7 & 196 & $\begin{array}{l}\text { More } \\
\text { frequent } \\
\text { control }\end{array}$ & $\begin{array}{l}\text { Fleet man- } \\
\text { ager, immedi- } \\
\text { ately }\end{array}$ & $\begin{array}{l}\text { Bearing } \\
\text { replacement, } \\
\text { lubrication }\end{array}$ & 4 & 7 & 6 & 168 \\
\hline
\end{tabular}

Similar procedure supplemented with FMEA and applied to all the defined locomotive assemblies and subassemblies provides a complete and complementary maintenance system, including particular operations required at a given time in order to maintain safe and correct use of the vehicle. However, irrespective of the method used once, according to which the inspection and repair operations have been distributed, continuous monitoring and observation of the condition of the vehicle operation remain necessary. Apart from the analysis based on the principles of reliability of particular components, final determination of the maintenance and repair cycles is affected by the vehicle operating conditions subjected to changes over time, according to the activity carried out by the carrier using these vehicles. Therefore, according to legislator's provision, the railway carriers operating the vehicles of a given type are responsible for proper development and updating of the documentation of vehicle maintenance system. In consequence, the maintenance system of a locomotive may vary according to the conditions of its operation existing at the carrier.
Postępując w podobny sposób wobec wszystkich zdefiniowanych zespołów i podzespołów lokomotywy, po przeprowadzonej analizie FMEA uzyskuje się kompletny i komplementarny system utrzymania zawierający poszczególne czynności wymagane $\mathrm{w}$ danym czasie $w$ celu zachowania bezpiecznej i prawidłowej eksploatacji pojazdu. Niezależnie jednak od zastosowanej raz metody, zgodnie z którą dokonano podziału czynności przeglądowo naprawczych, jest niezbędne by prowadzić ciagły monitoring i obserwacje stanu pojazdu. Oprócz analizy opartej o zasady niezawodności poszczególnych komponentów, wpływ na ostateczne ustalenie cyklów przeglądowonaprawczych mają warunki eksploatacji pojazdu, które mogą ulegać zmianie w czasie, w zależności od działalności prowadzonej przez przewoźnika z udziałem pojazdów. Dlatego też ustawodawca uczynił odpowiedzialnym za właściwe opracowanie i aktualizację dokumentacji systemu utrzymania pojazdów przewoźników kolejowych eksploatujących pojazdy danego typu. System utrzymania lokomotywy tego samego typu może zatem różnić się w zależności od tego w jakich warunkach przewoźnik wykonuje pracę eksploatacyjną z użyciem pojazdu. 


\section{Summary}

The adopted solution of a balanced maintenance cycle was based on the assessment of the technical condition of the locomotive. Due to uniform distribution in time and adjustment of the inspection ranges to the types of locomotive components and subassemblies, satisfactory reliability was achieved, ensuring, at the same time, compliance of the locomotive with its design criteria and manufacturer's requirements. Lower maintenance costs were also achieved as compared to other similar locomotive types subjected to five-level maintenance system.

This suggests that the method of a balanced maintenance cycle is a good alternative for the railway vehicle owners. Nevertheless, taking into account that it is a relatively new solution, monitoring of the locomotive condition and constant improving of the maintenance process is necessary. Additionally, the changing operating conditions may impose proper adaptation of the maintenance process or may require preventive operations resulting from failure frequency analysis or from FMEA.

\section{Podsumowanie}

Przyjęte rozwiązanie zbilansowanego cyklu utrzymania zostało oparte na ocenie stanu technicznego lokomotywy. Poprzez równomierne rozłożenie w czasie i dopasowanie zakresów przeglądów do rodzajów elementów składowych i podzespołów lokomotywy, osiagnięto satysfakcjonującą niezawodność zapewniając przy tym zgodność lokomotywy z jej kryteriami projektowymi i wymaganiami producenta. Uzyskano również niższe koszty utrzymania $\mathrm{w}$ porównaniu $\mathrm{z}$ innymi porównywalnymi typami lokomotyw, gdzie stosuje się pięciopoziomowy system utrzymania.

Pozwala to sądzić, że metoda zbilansowanego cyklu utrzymania jest dobrą alternatywą dla posiadaczy pojazdów kolejowych. Z uwagi jednak na to, że jest to relatywnie nowe rozwiązanie, należy monitorować stan lokomotywy i ciagle doskonalić przyjęty proces utrzymania, a w razie potrzeby dostosować go do zmieniających się warunków eksploatacji lub wprowadzać wymagane działania zapobiegawcze wynikające $\mathrm{z}$ wykonanych analiz awaryjności pojazdu lub metody FMEA.

\section{Bibliography / Bibliografia}

[1] Wachnik R., Drzewiecki A.: System Zarzqdzania Utrzymaniem pojazdów kolejowych (MMS). Zeszyty Naukowe Politechniki Ślaskiej. Katowice 2011.

[2] Rozporzqdzenie Ministra Infrastruktury z dnia 12 października 2005 r w sprawie ogólnych warunków technicznych eksploatacji pojazdów kolejowych (Dz. U. 2016 poz. 226 z późn. zm.).

[3] Dokumentacja systemu utrzymania, DB Cargo Polska S.A. Praca niepublikowana. 2017.

[4] Folejewska A.: Analiza FMEA - zasady, komentarze, arkusze. Wydawnictwo Verlag Dashofer Sp. z o.o. Warszawa 2010. 